\title{
A Seventeenth-Century Book Collector: Seigneur de Peiresc
}

Even though book collecting flourished in the seventeenth century, many private libraries were small and rather ordinary; thus, a library of thirty-five hundred volumes was considered special. John Locke had accumulated a library of thirty-four hundred works; Samuel Pepys's numbered about the same size. The celebrated English diarist, John Evelyn, owned a collection of five thousand books-an outstanding achievement for this period.

From his home in the remote region of southeastern France, isolated from the intellectual and publishing centers of Europe, NicholasClaude de Fabri, Seigneur de Peiresc, naturalist, philologist, numismatist, scientist, antiquarian, and dilettante par excellence, could count slightly less than six thousand tomes on his shelves. The size of a library, however, did not necessarily determine its importance. The Peiresc library was special because of the role this Maecenas of the Midi played in the seventeenth-century world of books. Peiresc acted as a catalyst in the book-publishing trade through his correspondence with authors, editors, and printers by encouraging, cajoling, and occasionally offering financial support in order to bring their ideas and works into print. One scholar described Peiresc's library as a kind of current national bibliography of books published in western Europe during the first four decades of the seventeenth century. The University of Iowa Library is fortunate that its holdings include not only printed materials about the life of this interesting Frenchman but also copies of many books listed in the Peiresc library.

Except for his letters, the best primary source about Peiresc's life remains the information supplied by the famous skeptic and Epicurean philosopher, Pierre Gassendi (1592-1655). His first extensive contact with this French amateur occurred while he held the chair of 
philosophy at Aix. Although Gassendi wrote his major works ${ }^{1}$ after the death of Peiresc, he acknowledged Peiresc's influence upon his intellectual development. Their friendship ripened with age. Gassendi kept in close contact with Peiresc when not in Provence and stayed at his side during his final illness. In Gassendi's astronomical diary, he noted that he felt too sad to make any observations this day (June 24,1637 ) because death had claimed his dear friend "the excellent Fabri, an incomparable man, greater than any praise that can be made about him." Soon thereafter he began writing an appropriate memorial to the one who had shared his scientific interests, had invited him to live in his home, and had become his closest acquaintance. In spite of the solemn and slightly hyperbolic tones of the Viri Illustris Nicolai Claudii de Peiresc, Senatoris Aquisextiensis Vita, ${ }^{2}$ it provides us with a clear and perceptive understanding of Seigneur de Peiresc. The life of Peiresc unfolds in this way.

Born on December 1, 1580 into an upper-middle-class southern French family near the town of Aix-en-Provence, Peiresc, described as a "delicate" child, demonstrated very early a wide and scholarly interest in many subjects, a characteristic that would stay with him his entire life. At age 19 he persuaded his father to send him to the University of Padua, where the personal contacts he made further awakened his intellectual curiosity. Studying there at the same time was the Englishman William Harvey, not yet the famous physician he was to become. It would be nice to think that the two youths from France and England discussed their mutual interests at a sidewalk cafe, but there is no evidence that they knew each other. Peiresc did meet another genius, Galileo, who was a member of the university staff. At the home of his friend Jean-Vincent Pinelli, antiquarian, professor of law, and owner of a magnificent library, picture gallery, and collection of artifacts, Peiresc learned his astronomy and mathematics from Galileo. Unfortunately, Peiresc had a career-oriented father who did not appreciate or understand his son's three-year academic program of conversation, study, and no degree. He summoned Peiresc home!

1 Exercitationes paradoxicae adversvs Aristoteleos. Amstelodami: Elzevirium, 1649; De vita et moribus Epicvri libri octo. Lvgdvni: Barbier, 1657; Petri Gassendi . . Opera omnia in sex tomos divisa. . . Lvgdvni: Anisson \& Devenet, 1658. These works and those cited in the following footnotes comprise the materials owned by The University of Iowa Libraries that relate to Peiresc or to individuals with whom he had some contact. Significant publications not owned by Iowa will be noted.

2 Parisiis: Cramoisy, 1641. The English translation is The Mirrour of true nobility \& gentility. Being the life of the renowned Nicolaus Claudius Fabricius lord of Peiresk ... London: Streater, 1657. 
Realizing now the need to complete his studies, Peiresc acquired a law degree at Montpellier. Before assuming his legal duties, however, he journeyed to Paris, where he formed a friendship with two men of letters, Pierre (1582-1651) and Jacques Dupuy (1591-1656). Through them he encountered Isaac Casaubon (1559-1614), the French classical scholar, and Auguste de Thou (1553-1617), historian and librarian of the king. Later Peiresc joined the entourage of the French ambassador leaving to take up his post in London. Unlike the other obnoxious young Frenchmen who were always part of such a group, he kept to himself and spent his time writing down titles he noticed in the London bookstalls, buying books he could afford, and collecting coins. He also added to his ever-increasing list of friends. This young man from the south of France met King James I and became acquainted with some of the well-known scientific and literary figures of English society. Traveling through Holland after his departure from England, Peiresc was introduced to Hugo Grotius (1583-1644) and J. J. Scaliger (1540-1609), the great classical scholar. Back in Aix he performed his duties as a member of the Parlement of Provence. The intellectual life of Paris, however, was of greater interest to him; as soon as an opportunity occurred, he returned to the capital, where he remained for seven years. This would be the most formative period of his life because as a member of an unofficial literary society of scholars he listened to and frequently discussed new ideas with some of the greatest names in French society, as well as with foreign scholars passing through the city.

When Peiresc finally returned to Aix and to his legal responsibilities, he also assumed the title of abbé of the monastery of Guitres. This position provided him with an income, although he managed not to live in the abbey or perform his ecclesiastical duties. With an adequate means of support, he took up residence in his summer home at Belgentier (just north of Toulon), except for trips to Aix to carry out his legal chores. Until his death in 1637, Peiresc remained busy cultivating his encyclopedic interests. He attempted to offer an explanation for the eruption of volcanoes; he examined coins and became one of the leading numismatists in Europe; he dissected the eyes of birds and fish in order to explain the phenomenon of vision (he owned one of the first microscopes in France); he made a map of the moon from the most recent scientific observations; he studied the writings of the troubadour poets; he wrote on the linguistic differences between Brittany and Provence; and he maintained a zoo of wild animals in order to study their behavioral patterns. Peiresc also had a mania for collecting. In addition to coins, Roman measures,

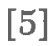


exotic plants and shrubs, manuscripts, and herbs, he had a love for cats-Angoras to be specific. These feline creatures were ubiquitous in his home. In spite of his scholarly interests, Peiresc published nothing. But he wrote letters and collected books.

In the early seventeenth-century there existed an international network of correspondents linking the intellectual communities of Europe. Through letters, scholars freely exchanged information on all topics. Peiresc remained the focal point of news about France, particularly for all southern France. He succeeded admirably in this task. Ill most of his life, Peiresc rarely left his bed before noon. There, wrapped in a shawl with a warm cap on his head and with the shutters still shut (surrounded by his Angora cats), he wrote letter after letter after letter or dictated them to his secretaries. One can only guess the total number he wrote. We do know, however, that between 1616 and his death in 1637, postal carriers delivered about seven thousand of his letters to all parts of Christendom. Some have been printed, ${ }^{3}$ but a larger number remain unpublished, found in libraries throughout France. Peiresc's correspondents literally comprised a who's who of Western Europe's literati.

He wrote, thought, and we might guess, dreamed about the world of books. In nearly every letter Peiresc made a reference to a book he had heard about that had just been published, a book he wanted to purchase, or a packet of books that had just arrived from a friend in some distant land. Any material that entered Peiresc's library received his close scrutiny. Even though he tried to replace any book printed with broken or worn letters, poor quality ink, and inferior paper, Peiresc was not a bibliophile in the true sense of the word. The contents of a work, whether it represented the best and most reliable edition, became his primary criterion. Books became the tools of his scholarly trade. He, therefore, made extensive marginal annotations in them to elucidate or emendate an idea the author presented. Peiresc also kept busy two bookbinders who bound his tomes in red Morocco leather with a distinctive tooled design on the front cover. Coberan, his favorite binder, once single-handedly prevented a mob from ransacking his house in Aix during a riot and setting a torch to his books. Even though Coberan succumbed too regularly to the charms of the grape, Peiresc could not forget that he had saved his beloved library and kept him on.

3 Philippe Tamizey de Larroque (ed.), Lettres de Peiresc in Documents inédits de l'Histoire de France. Paris: Imprimerie Nationale, 1888-1898, 7 vols. and 21 fascicules that appeared in various French periodicals between 1879-1897, which have been reprinted as Tamizey de Larroque (ed.), Les Correspondants de Peiresc. Genève: Slatkine, 1972, 2 vols. 
It is unfortunate that Peiresc never compiled a shelflist, or, better, a catalog of his library when he wrote his will and testament of June 22, 1637. The only attempt to do so was undertaken before he left for Paris in 1616. Though this 32-leaf manuscript recorded books in 17 divisions according to their location in his library, it was too incomplete to be trusted. In fact, Peiresc obtained most of his acquisitions between 1617 and his death two decades later. All his property he left to his brother, Palaméde Fabri Valavez, a bibliophile, though of lesser stature, who kept the library intact until his death in 1645. At that time the library, along with all other possessions, passed to Valavez's son, Claude Fabri, Baron, later Marquis, de Rians. Lamentably for the world of book collecting, the son had much different interests from his father or his famous uncle. Moreover, he was in debt. In 1645-46, Rians had two catalogs made of the Peiresc library as a means of advertising its contents to potential buyers. For a time it seemed as though the library collected by Peiresc would remain intact. Almost! Jules Mazarin, then first minister of France, heard about this famous library. He quickly authorized the librarian of his own collection, Gabriel Naudé, to travel to Aix, examine the material, and estimate its value. For reasons that remain yet unknown, Mazarin purchased only the nonpersonal manuscripts in the collection, which eventually became part of the Bibliothèque Nationale, where they are today. The books were unwanted. A pity! Eventually they were sold in separate lots by different booksellers to libraries, other booksellers, and bibliophiles. Today one finds books from Peiresc's study scattered in libraries throughout the world and, occasionally, titles listed in a bookdealer's secondhand catalog.

As might be expected, Peiresc's library contained copies of most books written by or associated with his multitudinous correspondents. This was particularly true of his English friends. The contacts Peiresc made with scholars during his visit to England developed steadily over the years and became beneficial to both parties. Because of his epistolary network throughout the continent, Peiresc introduced the published works and current research projects of Englishmen to European scholars, some of whom wrote directly to their English counterparts. Peiresc considered the advancement of scholarship to be primus inter pares; therefore, he did not hesitate to draw upon any unique printed sources or manuscripts held in England. The best example of pooling scholarly resources, although the result never appeared on the shelves of the Peiresc library, involved his association with the antiquarian and collector, Robert Cotton (1571-1631). While in England Peiresc had the opportunity to examine carefully Cotton's 
library holdings, especially his magnificent collection of manuscripts. Some years later he wrote to his friend William Camden, with whom he felt on better terms than Cotton, and asked if he could persuade Cotton to lend him the Greek manuscript Genesis. A group of French scholars, who were preparing a new Greek edition of the Bible, needed it. After numerous proddings from Peiresc, the original manuscript arrived in Paris, where it remained for more than four years. Camden, embarrassed by the duration of the loan, repeatedly importuned his French friend to return the manuscript. The English ambassador in Paris, pressured by Camden, exerted pressure, and Peiresc reluctantly returned the manuscript (apparently he never thought the length of time excessive). But Peiresc was not the procrastinator in this episode. A slow-working French scholar had not completed his part of the manuscript and an artist commissioned to copy the illustrations had not fulfilled his commitment. Peiresc expressed concern for the great loss to society if this precious treasure should be destroyed before scholars had the opportunity to reproduce it completely. This clairvoyant comment came true a century later when a fire damaged part of the Greek manuscript Genesis. The new Greek Bible, which was taken, in part, by the French scholars from the loaned Genesis manuscript, now became a valuable source in the reconstruction of the ruined Cotton manuscript. ${ }^{4}$

Peiresc's contact with other Englishmen, that is, Camden, Selden, and Harvey, had a more direct influence on the growth of his library. In his first meeting with William Camden (1551-1623), Peiresc recognized in him someone who shared his interests and philosophical view of history. Their antiquarian tastes led them to consider history in a way that stressed the genealogical and etymological nature of the discipline. Even the difficulties surrounding the Genesis manuscript did not sever their professional ties. Peiresc kept abreast of Camden's latest publication and current research project. When he received from him a copy of the sixth edition of the famous Britannia, ${ }^{5}$ Peiresc discovered a map missing and a few torn pages. He asked his brother, who was about to set off on a tour of Europe, which included a visit to London, to obtain a perfect copy from the printer or, if not, from

4 Catalogus librorum manuscriptorum Bibliothecae Cottonianae. Oxonii: Sheldoniano, 1696. This is the first major printed catalog of the Cotton manuscript collection.

5 Though Iowa does not own a copy of the 6th ed. of 1607, it possesses copies of two later editions of Britannia. London: Bowyer, 1772, 2 vols. and London: Nicholas, 1789, 3 vols. 
the author. As might be expected, Peiresc also owned: the other writings of Camden. ${ }^{6}$

Peiresc's abiding interest in books and manuscripts about the Middle East and East Indies brought him in contact with John Selden (15841654), Orientalist and jurist. Selden's fine collection of Oriental manuscripts that he eventually bequeathed to the Bodleian Library became the basis for his De Diis Syris (1617); in the introduction to this book he thanked Peiresc for the encouragement he had provided him in this project. As a jurist Selden took issue with what he considered to be the usurpation of the rights of Parliament by the crown, and he put his feelings and ideas into print. His History of the Titnes so impressed Peirese that he predicted it would soon be translated into French. ${ }^{7}$

In August of 1629 a courier brought Peiresc news from the famous Frankfurt Bookfair that he had seen a copy of a new book by the English physician William Harvey (1578-1657). Though Peiresc had not corresponded recently with Harvey, he knew from his other scientific acquaintances in England and western Europe about Harvey's theory of the circulation of the blood. Letters quickly went out from Aix to his bibliographical contacts in Paris beseeching them to buy him a copy of this book. Within three weeks the Provençal savant placed his ex libris on the Exercitatio Anatomica de Motu Cordis et Sanguinis in Animalibus. ${ }^{8}$

The Englishmen John Barclay and Henry Spelman both owed the publication of one of their books to the direct involvement of Seigneur de Peiresc. Barclay, a political satirist and Latinist, became a great friend of the Frenchman and during the course of his life (1582-1621) they exchanged over one hundred letters. Anyone Peiresc knew traveling to London received instructions to deliver letters, Latin verse, or

6 Anglica, Hibernica, Normannica, Cambrica . . Francofvrti: Marnij \& Aubrij, 1602; Annales. London: Fisher, 1625; The History of ... Princess Elizabeth. 4th ed. London: Flesher, 1688; and Epistolae. London, 1691.

7 Titles of honor. London: Stansby, 1614 and London: Dring, 1672; The Historie of tithes. [London], 1618; The Priviledges of the baronage of England. London: Badger, 1642; Metamorphosis Anglorum, The Hague, 1653; The Antropos. London, 1661; Of the judicature in Parliaments. London: Lawson, 1681; The Duello. London: Bray, 1711; Opera Omnia. Londini: Bowyer, 1726, 3 vols.

8 Though Iowa does not own the Francofvrti:Fritzeri, 1628 edition it has an interesting collection of Harvey materials: De Motu Cordis. Lugduni Batavorum: Maire, 1639 as well as editions dated 1645, 1654, 1680, 1671, 1697, 1736, 1751, and the uncommon 1753 edition; Exercitationes de generatione animalium. Londini: Gardianis, 1651; Anatomical exercises. London: Leach, 1653; and Opera Omnia [Londini: Bowyer, 1762.] 
books to the Barclay residence at King Street. Barclay had written a Latin satire on the role of political factions and conspiracy, which remained unpublished. Peiresc recommended a reliable and skilled printer-publisher in Paris, Nicholas Buon, whom he knew would be interested in the manuscript. Not only did Barclay accept Peiresc's suggestion, but he allowed his friend to have a portrait made of him that appeared in the first edition of Argenis. ${ }^{9}$ The historian and antiquarian Henry Spelman (1564-1641) achieved his scholarly reputation first on the Continent and later in England because, in part, of the association with a fellow antiquarian, Peiresc. When Spelman sent his son on a tour through Europe, he obtained from Camden, who had closer ties with European scholars, letters of introduction. Camden's friend from the Midi was living in Paris at the time and provided an unusually warm reception for the young man. Peiresc gave him a "Cook's tour" of the intellectual and cultural sights of the capital as well as a personal introduction to the luminaries of Parisian society: Jérôme Bignon, Philip Maussac, Gilbert Gaulmin, Nicholas Rigault, and others. In addition to describing his collecting interests and current research (that incidentally bored Spelman), Peiresc obtained from him proofsheets of his father's glossary of obsolete Latin and old English terms that the elder Spelman had been working on for many years. Peiresc circulated the material among his French friends, collected their comments, and forwarded the suggestions to Camden and the author. The scholarly community in France insisted that Spelman should bring his research into print, and they did not hesitate to write to him about it-especially Peiresc. Although he felt his work was not yet ready for the public, Spelman followed their advice. Volume one of the Glossarium Archaiologicium that covered only through the letter " $L$ " appeared in 1626 and was followed 18 years later by the completed work. ${ }^{10}$ The preface (volume one) included appropriate acknowledgements to French scholars with special attention given to his friend, Peiresc.

The early years Peiresc spent studying in Italy brought him in contact with Italian scholars who became part of his network of correspondents. Though he exchanged few letters with Jean-Vincent Pinelli (1535-1601), Peiresc had special affection for his Italian maestro. Pinelli did more than introduce his young dilettante to the intellectual

9 Pariis: Bvon, 1621. This edition is not found at Iowa. It has the Lvgduni Batavorum:Elzeriana, 1627 and Lvgduni Batavorum:Hackii, 1659 editions as well as the Pietas. Pariis: Mettayer, 1612.

10 Iowa lacks the 1626 edition but it owns the later edition, Londini: Warren, 1664 and The English works of Sir Henry Spelman. London: Browne, 1723. 
challenges of serious collecting. He treated him as an equal (though their age difference represented 45 years), and he invited him into his home to meet Italian scholars. It gave Peiresc a special pleasure to see a copy of the life of Pinelli on his library shelves. ${ }^{11}$ The most noteworthy figure Peiresc encountered through his Italian connection was Galileo Galilei (1564-1642). His scientific achievements were well known to Peiresc, who attempted to secure a copy of all his writings, which he and Gassendi eagerly discussed. In 1632 Peiresc noted in a letter to his bibliographical friend in Paris, Jacques Dupuy, that he feared the current blockading of trade between Italy and France would prevent him from obtaining a copy of Galileo's most recent book. Every letter exchanged between Peiresc and Dupuy in the fall of that year contained a report on the Galileo book he had purchased and where it might be between Florence and Aix: it had not yet left Florence; it had reached Toulon by ship; it had arrived in Marseilles; but a recent outbreak of the plague kept it in the city. At long last the Dialogo reached its impatient owner. ${ }^{12}$ Peirese had a difficult time understanding Galileo's problems with the Roman Catholic Church. He wrote frequently to his friend Cardinal Barberini and any others he knew living in Rome asking them to do everything possible to aid this beleaguered scientist.

Peiresc's relationships with the jurist Hugo Grotius and his involvement with Grotius's famous work on international law (De Jure Belli ac Pacis) offer another facet to the versatile interests of the Provençal savant. Grotius first encountered the erudite young man in 1606 on his return home to Aix. Grotius's serious legal and religious problems with his government, which eventually led to his arrest, incarceration, and escape from prison, prevented him from keeping in contact with Peiresc. Offered political asylum by the French government, Grotius took up residence in Paris and in the surrounding provinces where he struggled to continue his research and writing while attempting to obtain financial support from the king. During this period Peiresc encouraged Grotius in his scholarly work and probably suggested to him the name of the printer Nicholas Buon, who had earlier published Barclay's Argenis. In July 1624 Grotius acknowledged this

11 Paolo Gualdo. Vita Joannis Vincentii Pinelli. Augustate Vindelicorum: [Mangus], 1607 .

12 Fiorenza: Landini, 1632. Iowa has significant Galileo publications: Difesa contra calunnie \& imposture di Baldessar Capra. Venetia: Baglioni, 1607; Discorso della comete di Mario Guiducci. Fiorenza: Cecconcelli, 1619; Il Saggiatore. Roma: Mascardi, 1623; Della scienza mecanica. Ravenna: Camerali, 1649; Discorso al Serenissimo Don Cosimo 1I. Bologna: Dozza, 1655; Opera. Bologna: Dozza, 1655-1656, 2 vols.; Systema comicum. Londini: Dicas, 1663. 
support by writing to Peiresc: "I continue with my work. If it proves of value to readers, it is to you to whom posterity will be indebted, since it was you who have continually encouraged me." De Jure Belli ac Pacis appeared one year later. ${ }^{13}$ The French, as might be expected, interpreted Grotius's statement and other information contained in the letters the two scholars exchanged to mean that Peiresc was responsible for Grotius publishing his classic work on international law. Dutch historians disagree. They argued the Frenchman's role was inconsequential; he knew nothing about the subject matter and, therefore, had no influence on Grotius or on his work. They dismissed Grotius's effusive praise of Peiresc as following the social custom of seventeenth-century French society. This controversy has generated more heat than light among the legal and historical combatants. The accepted interpretation maintains that Peiresc encouraged Grotius in his research without knowing in much detail the subject of his great work, and since the Frenchman knew a reliable printer he recommended him to Grotius. The exact involvement of Peiresc with the De Jure Belli ac Pacis is of no major importance (except to French and Dutch nationalists). Peiresc was simply doing what he had been doing his entire life: encouraging an author to put his research and ideas into print. ${ }^{14}$

Few books of nonfiction written by Frenchmen during Peiresc's lifetime escaped his notice. In many instances he had corresponded extensively with the authors (usually they became close friends), had encouraged them to publish their research, had recommended the name of a printer, and always, had requested that a copy of their books be sent to him. Peiresc occasionally encountered disagreeable writers, or ones whose ideas he could not accept; yet, their books still became part of his library.

Two seventeenth-century French scholars who achieved greater respect and recognition within the scholarly community of western Europe than Peiresc were Gabriel Naudé and Marin Mersenne. Though Naudé (1600-1653) was 20 years Peiresc's junior, the lifestyles and interests of both men followed remarkably similar patterns:

13 Iowa does not own the Parisiis: Bvon, 1625 edition, but its holdings include a Latin edition: Amstelaedami: Blaev, 1670 and a French edition La Drait de la Guerre et de la Paix. Amsterdam: Coup, 1724, 2 vols.

14 Other significant Grotius materials at Iowa are Defensio fidei catholicae. Lvgduni Batavorum: Patius, 1617; Grollae obsidio. Amstelaedami: Blaevz, 1629; De Mari Libero. Lvgduni Batavorum: Elzeviriana, 1633; Epistolae ad Gallos. Lvgduni Batavorum: Elzeviriorum, 1648; Hugo Grotius, his most Choice Discourses. London: Lee, 1669; and De Veritate religionis christianae. Amstelaedami: Plaats, 1709. 
abstemious in their diets, temperate in their feelings, but zealous in their love of books. In 1627 Peiresc received from Dupuy a copy of Naudés Advis pour dresser une bibliothèque. ${ }^{15}$ This classic in the field of library acquisition, organization, and administration did not impress Dupuy, who described the 27-year-old author as a novice in what he pretended to be knowledgeable in. Peiresc did not agree. When Naudé became librarian in Rome, Peiresc drew on his bibliographical expertise to keep abreast of the publishing activities in Italy. Postal couriers traveling between Aix and the Eternal City carried Peiresc's interminable questions about the title of a recent book, the publication date of a special edition, or the possibility of Naudé obtaining for him copies of certain books; on the return trip their pouches contained Naudés replies, news about the publishing world, and, usually, books for his Provençal friend. Naudé would examine many of these same books again. Later in his role as librarian for the Mazarin collection in Paris, Naudé traveled throughout Europe buying materials that would soon make this library the finest in all France. It was, we recall, in this capacity that Naudé journeyed to Aix in 1645, eight years after Peiresc's death, to examine the manuscripts and books (some of which he recognized) in this magnificent library now being offered for sale by an impecunious nephew.

Mersenne (1588-1648) was the most intellectually active person Peiresc knew. His mathematical, scientific, and philosophical contributions to the seventeenth century won him admiration from many quarters. ${ }^{16}$ His association with Gassendi brought him in contact with Peiresc, who quickly became one of his closest friends. This relationship provided Peiresc with the opportunity to observe a great mind in action; it gave a dilettante of Peiresc's ilk the dramatic realization of the contrast between an amateur and a scholar. But Mersenne benefited as well from this relationship. Besides encouraging him in his research, offering him lodgings in his homes in Aix and Belgentier, Peiresc assisted Mersenne in the publication of one of his works. Mersenne had developed an interest in and a knowledge of music. Although in all likelihood Peiresc had only minimal background in this field, he had faith in his friend's research and paid part of the expense for printing

15 Paris: Targa, 1627. The Naudé works held by Iowa also include Ivgement de tovt ce qui a esté imprimé contre le Cardinal Mazarin. 2nd ed. Paris, 1650 and two minor publications: Apologie ... qui ont este accusez de magie. Paris: Cotin, 1669 and Apologie pour les grandes hommes soupçonnez de magie. Amsterdam: Bernard, 1712.

16 Cogitata physico-mathematica. Parisiis: Bertier. 1644 and Novarvm observationvm physico-mathematicarivm. Pariis: Bertier, 1647. 
l'Harmonie Universelle, a study of the theory, harmonics, and acoustics of music. 17

Guillaume Duvair and André Duchesne had a special influence on the Provençal savant. The Peiresc-Duvair relationship confirmed a pattern that had occurred many times in Peiresc's life: similar interests, and not age similarities, solidified a friendship. Duvair (15561621), two decades Peiresc's senior, had considerable experience in the judicial system as president of the Parlement of Provence before he encountered Peiresc. Initially their mutual interest in law drew them together, but their love and admiration for scholarship became the cohesive element in their friendship. Duvair admitted his new acquaintance into a close circle of friends who met at La Floride, Duvair's home near Aix, where they discussed the latest scientific, literary, and historical writings. Though this group was a poor imitation of similar ones in the capital, it gave Peiresc, now in his 20s, more taste of the heady wine of intellectual society. When Duvair was called to Paris by the king, he took his young friend as his personal secretary. Duvair was obliged to return to Provence soon, but Peiresc stayed on and eventually joined the retinue of the French ambassador to England. Peiresc recognized the value these contacts had in furthering his bibliographical interests, and he never forgot the kindness Duvair had shown him. Although only two of Duvair's books appeared during his lifetime, ${ }^{18}$ Peiresc worked to have published a more complete record of his mentor's writings. He found an unusually gifted editor, André Duchesne, to handle this chore.

As one of France's most reputable historians, Duchesne (1584-1640) has been called the "father of the history of France." His appointment as geographer and historiographer of the king recognized his talents. He published his first work at age 18, and before his death he had written or edited 23 more works, many multivolumed.19 Peiresc's first significant contact with Duchesne occurred in his relationship with the English scholar Camden. Aware that Duchesne was preparing a work on Norman history and that Camden had collected texts on that subject, Peiresc convinced his English friend to

17 Paris: Cramoisy, 1636-37. Not at Iowa. Iowa has a facsimile edition of a copy annotated by the author.

18 Recveil des harangves et traitez du Sr Dvvair. Paris: L'Angelier, 1607 and Les Oeuvres du Sr Duvair. Genève: l'Abbé, 1610.

19 Three of Duchesne's publications in Iowa's library (as well as below) are: Bibliotheqve des avthevrs qui ont escrit l'histoire et topographie de la France. Paris: Cramoisy, 1627; Histoire de la maison de Chastillon svr Marne. Paris: Cramoisy, 1621; and Historiae Francorvm scriptores coaetanei. Lvtetiae Parisiorvm: Cramoisy, 1636-1649, 5 vols. 
supply Duchesne with any texts he had and any others he could locate in England. The Historiae Normannorum Scriptores Antiqui sent to the printer in 1619 was an unusual and useful collection of sources on Norman history. ${ }^{20}$ It was quite natural, therefore, that Peiresc should seek out Duchesne to help edit the complete works of his friend Duvair. The publication that finally appeared in 1624 probably represented the joint labors of Duchesne, Jérôme Bignon, and François de Malherbe. Peiresc was displeased with the final product and placed the blame on the greedy business designs of the printer-publisher, Estienne Verevl, who blatantly ignored his advice and that of Duchesne. ${ }^{21}$

Peiresc's activities as a book collector demonstrated the camaraderie that existed among bibliophiles, dilettantes, and scholars: they knew one another, respected one another, exchanged research with one another, and lent one another books they thought might be of interest. This Provençal savant acted as a connecting link to these groups. But he did much more than that. Whether persuading a friend to convert his research into a book, chastising an English scholar for prepaying a courier who arrived with books, sending an agent to a bookfair to buy books, or providing a cleric with funds to publish his bookbooks, and the final product, a library, were the life of Seigneur de Peiresc.

20 Lvtetiae Parisiorvm, 1619.

21 Les Oevores dv Sr Dveair. Roven: Verevl, 1624. Not at Iowa. 


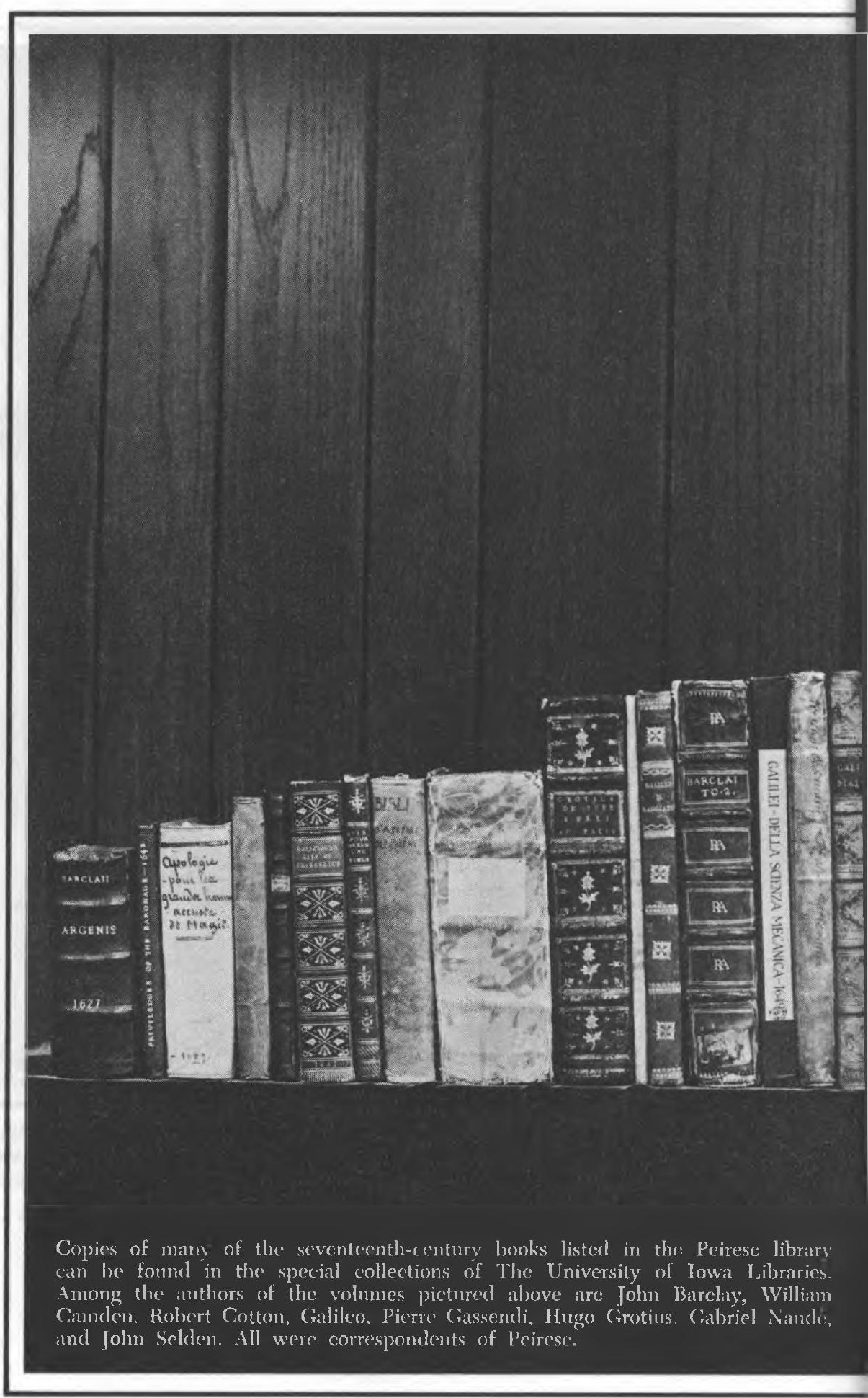

[32] 


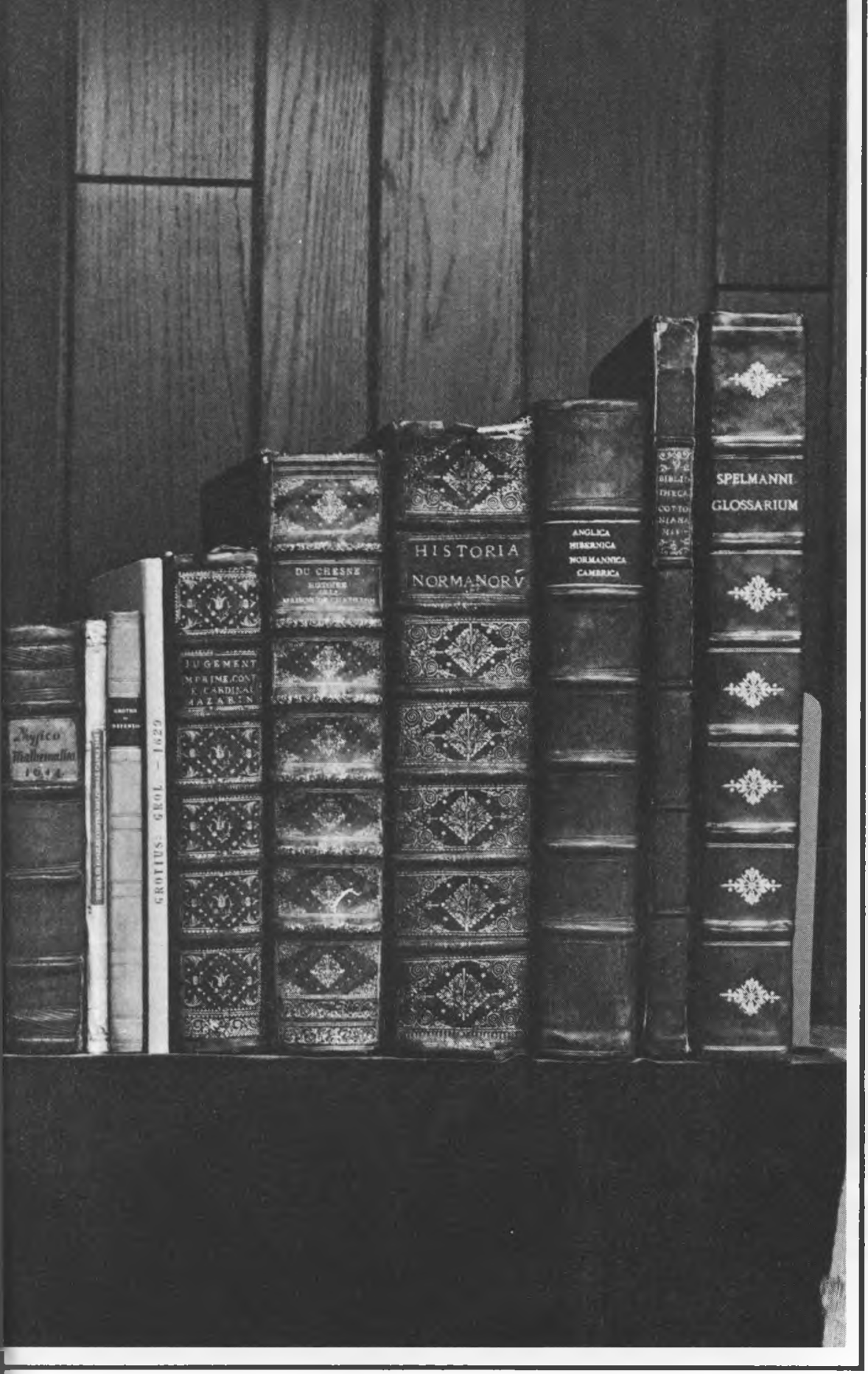

[33] 